\title{
Conference Summary
}

\author{
Philippa Marrack ${ }^{1,2,3}$ \\ ${ }^{1}$ Howard Hughes Medical Institute and Integrated Department of Immunology, National Jewish Medical and Research Center; and \\ ${ }^{2}$ Department of Biochemistry and Molecular Genetics, and ${ }^{3}$ Department of Medicine, University of Colorado Health Sciences Center, \\ Denver, Colorado
}

At the June 2006 Thomas L. Petty Aspen Lung Conference, a number of diseases that have consequences for the health of the lung were discussed. There was general agreement that some of the lung pathology observed in many of these diseases, including berylliosis, sarcoidosis, scleroderma, interstitial lung disease, and perhaps even chronic obstructive pulmonary disease, was caused by the action of the innate and/or specific immune system. The degree to which foreign antigen stimulation was involved was the subject of intense debate. In many cases antibody appeared to be the damaging agent. All these data suggest that direct modulation of innate and specific immunity is of value in these diseases.

The immune response affects the health of the lung in many ways. Because innate and specific immunity are the second barrier, after the epithelium, to infection, the most important and most obvious way in which the immune system affects the lung is by protecting it from infection and/or by driving rejection of invading organisms that have taken hold of the organ. Even this most beneficial consequence of immunity is not without its perils because immune responses to invading organisms can have, directly or indirectly, harmful consequences for the tissues of the lung, by killing virally infected cells, by causing granulomas that reduce the efficiency of the lung, or through bystander damage of lung cells due to the products of inflammatory responses and cells.

This conference was not designed to deal with the beneficial effects of the immune system in the lung, most of which is taken for granted. Nor, on the whole, did it deal with the consequences of collateral damage, caused by direct recognition of invading organisms in the organ, although this issue did come up during discussions of certain diseases. In addition, the effects of immune recognition of noninfectious antigens in the lung, such as those that lead to asthma, were also not considered. That is not to say that the effects of immune responses to foreign agents were ignored. Some effects of tuberculosis were discussed (see above) and unusual, nonallergenic antigens, such as beryllium, were included. A list of the diseases discussed, and the likely involvement of the innate or specific immune response in the disease, are shown in Table 1.

Several basic science approaches to understanding and solving problems in the lung were also brought up. This summary discusses the new ideas that came up, in basic science and in each of the diseases featured by the conference, and then recaps the major conclusions of the meeting.

(Received in original form August 1, 2006; accepted in final form March 10, 2007) Supported in part by United States Public Health Service Al-18785, Al-17134, $\mathrm{Al}-52225$, and Al-22295.

Correspondence and requests for reprints should be addressed to Philippa Marrack, Ph.D., Integrated Department of Immunology, National Jewish Medical and Research Center, Denver, CO 80206. E-mail: marrackp@njc.org

Proc Am Thorac Soc Vol 4. pp 469-471, 2007

DOI: $10.1513 /$ pats.200608-150MS

Internet address: www.atsjournals.org

\section{THE IMMUNE SYSTEM: NEW TECHNOLOGIES AND NEW IDEAS}

$\mathrm{T}$ cells have long posed problems to the experimentalist. First of all, instead of reacting with native antigen, their receptors for antigen (TCRs) usually react with peptides derived from foreign material, bound to the grooves of major histocompatibility complex $(\mathrm{MHC})$ proteins $(1,2)$. Thus the targets of $\mathrm{T}$ cells, unlike those of B cells and antibodies, cannot be identified by simple screens with protein extract and the usual kinds of bacterial expression libraries. The property has made it difficult to identify target antigens of the activated $\mathrm{T}$ cells that appear in numerous human diseases, in the absence of obvious stimulation by an external infectious agent. To deal with this problem, J. Kappler and colleagues have invented a way to make large libraries consisting of variable peptides bound to particular human or mouse MHC proteins (3). These libraries can be screened with TCRs from activated $\mathrm{T}$ cells of interest, for example, those that accumulate in the lungs of patients with berylliosis or sarcoidosis, in the hope of identifying the target peptide, and hence the target protein, in the disease.

Techniques have been invented that allow identification of $\mathrm{T}$ cells specific for particular MHC-peptide combinations. These techniques, which use multimers of MHC-peptide, often called "tetramers," have been successfully used in many animal and human diseases. For example, J. D. Wilson and colleagues have used the methods to monitor human immunodeficiency virusspecific $T$ cells in humans infected with the virus (4) and M. Davis and P. Lee and their colleagues have used the method to identify melanoma-specific, potentially cytotoxic, $\mathrm{T}$ cells in patients with this type of tumor (5). However, such methods cannot always be used and, in its stead, mouse immunologists have long relied on the use of $\mathrm{T}$ cells bearing transgenic TCRs, specific for a particular MHC-peptide combination. Such cells can be transferred in detectable numbers and thus allow analysis of the fates of antigen-challenged T cells in animals. A talk at this meeting by M. Jenkins, however, suggested that these T cells may not be good representatives of endogenous cells because transgenic T cells appear to compete with each other for survival in animals, whereas the heterogeneous pool of host cells, which may be specific for the same antigen, do not $(6,7)$. How such competition occurs is not known, but the guess is that the monoclonal pool of transgenic T cells somehow competes for recognition of a particular MHC-host peptide combination.

We are in great need of more and better models of human disease in mice. For example, the scorn of human allergists for mouse models of asthma is well recognized. At this meeting R. Torres and J. Hartney introduced a new mouse model for chronic obstructive pulmonary disease. The mouse disease is caused by absence of Lsc, a protein required for neutrophil migration (8). The investigators showed preliminary results that patients with chronic obstructive pulmonary disease may also have lower levels of this protein. New animal models for vasculitis (D. C. Baiu [9]), fibrosis (A. Babu), and Hermansky-Pudlack syndrome (10) (L. R. Young) were also described. 
TABLE 1. INVOLVEMENT OF THE IMMUNE RESPONSE IN VARIOUS LUNG DISEASES

\begin{tabular}{|c|c|c|c|c|c|c|}
\hline \multirow[b]{2}{*}{ Disease } & \multirow[b]{2}{*}{ Species } & \multicolumn{2}{|c|}{ Innate* } & \multicolumn{2}{|c|}{ Specific* } & \multirow[b]{2}{*}{ Presenter(s) ${ }^{\dagger}$} \\
\hline & & Causative & Present & Causative & Present & \\
\hline Sarcoidosis & Human & & Yes & Yes & Yes & $\begin{array}{l}\text { M. Falta; W. P. Drake; M. D. Rossman; } \\
\text { M. C. Iannuzzi; J. Grunewald; } \\
\text { D. R. Moller; W. P. Drake; E. S. Chen }\end{array}$ \\
\hline Bronchiectasis obliterans & Human & & Yes & Yes & Yes & J. W. Chien \\
\hline Beryllium disease & Human & & Yes & Yes & Yes & B. E. Palmer \\
\hline Scleroderma & Human & & Yes & & Yes & R. du Bois \\
\hline Silicosis & Human & Yes & Yes & & & G. Davis \\
\hline Interstitial pulmonary fibrosis & Human & & & & & \\
\hline Nonspecific interstitial pneumonia & Human & & Yes & Yes & Yes & K. Brown; S. K. Danoff \\
\hline Usual interstitial pneumonia & Human & & Yes & Perhaps not & Perhaps not & K. Brown \\
\hline Hypersensitivity pneumonitis & Human & & Yes & & & \\
\hline Vasculitis & Mouse & & Yes & Yes & Yes & D. C. Baiu \\
\hline Bacillus subtilis infection & Mouse & & Yes & & Yes & P. L. Simonian \\
\hline Hermansky-Pudlack syndrome & Mouse & Yes & Yes & & & L. R. Young \\
\hline Chronic obstructive pulmonary disease & Mouse & & Yes & & & J. Hartney \\
\hline Pulmonary vascular remodeling & Mouse & $?$ & Yes & & & G. Grunig \\
\hline
\end{tabular}

* Blanks indicate this subject was not discussed and/or the answer is not known.

$\dagger$ Only the first authors of papers are listed.

\section{SEARCHING FOR THE ANTIGEN}

If the specific immune response is involved in a particular lung disease, then we should be able to identify the target of the immune response and understand why that target is so crucial for the disease, and how it is being recognized. A number of methods to find the target were discussed, from the sophisticated (e.g., the MHC-peptide libraries discussed above) to the relatively simple, using antibodies. The idea that antibodies in sera would reveal the target of diseases is one of the oldest in the history of immunology. Certainly antibodies will tell us the targets of B cells, but it is also likely that antibody reactivity will reveal the origins of peptides that stimulate $\mathrm{T}$ cells in disease, given the well-known fact of linked recognition: $\mathrm{T}$ and $\mathrm{B}$ cells tend to react with covalently linked moieties.

In some lung diseases not discussed at this meeting the target antigens of antibodies are well known; they are the allergens common to our environment. In other lung diseases, the antigens recognized by antibodies associated with the disease are also well known, for example, the aminoacyl synthetases and nuclear antigens in interstitial lung diseases $(11,12)$. Antibodies were well employed by D. R. Moller and colleagues, who used the well-known diagnostic test for sarcoidosis, namely the reaction with diseased tissue from other patients, to find the target antigen, Mycobacterium tuberculosis catalase/peroxidase (13). Knowledge of the antibody target should allow investigators to identify the peptides recognized by $\mathrm{T}$ cells, but this has not yet been done for these antigens.

In the case of beryllium disease the target antigen, or at least the causative agent, is well known to be beryllium itself (14-16). However, beryllium is a small ion with complex chemistry, existing in various hydrated or other forms. Moreover, beryllium can coordinate with several amino acids. Thus the way in which beryllium is recognized by $\mathrm{T}$ cells remains a mystery, despite intense investigation.

More important, however, for human health is the following question: Will knowledge of the antigen involved in the disease help with treatment? If the antigen is an infectious agent, as appears to be the case for at least some patients with sarcoidosis, then antibiotics might do the trick. However, anti-M. tuberculosis reagents have yet to be useful in sarcoidosis. The target antigen may be even less useful in cases where it is not from an infection. Knowledge of the antigen has yet to be useful in the treatment of autoimmune diseases in which the antigen is known. For example, insulin is a target for antibodies in patients with diabetes before and after development of overt disease. Nevertheless, attempts to treat individuals who may be predisposed to diabetes with low-dose insulin therapy, to tolerize the immune response or to reduce targeting of pancreatic beta cells, have not prevented disease (17). Whether this is because insulin is not the right target, or because the tolerization/reduction of target strategy did not work, or because there is a flaw in the logic of the entire endeavor, is not known.

Even if knowledge of the target antigen is not useful in treatment, it may help in understanding lung diseases. With respect to this point, autoimmune disease may also prove to be a useful model.

\section{CHEMOKINES}

Many of the talks focused on chemokines, produced by the lung tissue itself, or other cells, and on the idea that cellular recruitment and activation by chemokines contributed to lung pathology. While the idea that manipulation of chemokines and their receptors is certainly not new, the numbers of times chemokines were invoked at this meeting (Table 2) suggested renewed interest in these important proteins. Unfortunately, drug company representatives at the meeting were reluctant to expand on the subject, so we were left ignorant of the latest possibilities for therapy involving chemokines.

\section{B CELLS AND ANTIBODIES}

Galling as it may be for those who have spent most of our scientific lives studying $\mathrm{T}$ cells, there is evidence that B-cell products may be more useful and/or more damaging in human diseases than $\mathrm{T}$ cells are, or at least, targeting $\mathrm{B}$ cells may prove one of the most valuable therapies. As far as the use of antibodies as therapeutic reagents is concerned, it is now well accepted that monoclonal antibody therapies are useful in many diseases. At the meeting B. L. Kotzin discussed the use of anti-tumor necrosis factor (TNF) reagents either in the form of antibodies or as solubilized TNF receptors. He mentioned that TNF blockade is proving useful not just in autoimmune diseases such as rheumatoid arthritis but also in other diseases that have an inflammatory component, such as atherosclerosis and perhaps even asthma. 
TABLE 2. CHEMOKINES AND CHEMOKINE RECEPTORS AS TARGETS IN LUNG DISEASE

\begin{tabular}{|c|c|c|c|}
\hline Chemokine & Disease & Goal of Treatment & Presenter \\
\hline $\mathrm{CCL} 2 / \mathrm{CCL} 22$ & Scleroderma & $\begin{array}{l}\text { Reduce macrophage and NK cell infiltrates, } \\
\text { the size of which correlate with disease } \\
\text { severity }\end{array}$ & M. P. Keane \\
\hline CCL2 & Silicosis & $\begin{array}{l}\text { Reduce macrophage and NK cell infiltrates, } \\
\text { the size of which correlate with disease } \\
\text { severity }\end{array}$ & G. Davis \\
\hline CCL17 & Lung cancer & Attract lymphocytes & \\
\hline CCL17 & Epithelial cell hyperplasia & Reduce lymphocyte recruitment & J. W. Tichelaar \\
\hline $\begin{array}{l}\text { Lsc (a mediator of } \\
\text { chemokine responses) }\end{array}$ & COPD & Reduce neutrophil infiltrates & J. Hartney \\
\hline CCL5/19/21 & Lung inflammation & Reduce dendritic cell migration & M. H. Grayson \\
\hline CCR2 & Sarcoidosis & Polymorphisms affect disease in humans & M. C. Iannuzzi \\
\hline CXCR2 & Graft rejection & Prevent rejection & \\
\hline
\end{tabular}

Definition of abbreviations: COPD = chronic obstructive pulmonary disease; NK cell = natural killer cell.

Along a different line, anti-IgE therapies are useful in asthma and B-cell depletion with rituximab is a valuable treatment for vasculitis and Wegener's granulomatosis (discussed at the meeting by J. M. Goblin).

\section{CONCLUSIONS}

The meeting proved its point: many lung diseases have an immune component. Inflammation is always evidence of the activity of innate immunity, but in many cases there is evidence that a specific immune response, against an environmental agent or against self, plays a role. The extent to which this is true, and the extent to which manipulation of the nonspecific or specific immune response will turn out to be useful, remains to be seen.

Conflict of Interest Statement: P.M. does not have a financial relationship with a commercial entity that has an interest in the subject of this manuscript.

\section{References}

1. Bjorkman PJ. MHC restriction in three dimensions: a view of $\mathrm{T}$ cell receptor/ligand interactions. Cell 1997;89:167-170.

2. Marrack P, Kappler J. The T cell receptor. Science 1987;238:1073-1079.

3. Crawford F, Jordan KR, Stadinski B, Wang Y, Huseby E, Marrack P, Slansky JE, Kappler JW. Use of baculovirus MHC/peptide display libraries to characterize T-cell receptor ligands. Immunol Rev 2006;210:156-170.

4. Wilson JD, Ogg GS, Allen RL, Davis C, Shaunak S, Downie J, Dyer W, Workman C, Sullivan S, McMichael AJ, et al. Direct visualization of HIV-1-specific cytotoxic $\mathrm{T}$ lymphocytes during primary infection. AIDS 2000;14:225-233.

5. Yee C, Savage PA, Lee PP, Davis MM, Greenberg PD. Isolation of high avidity melanoma-reactive CTL from heterogeneous populations using peptide-MHC tetramers. J Immunol 1999;162:2227-2234.

6. Foulds KE, Shen H. Clonal competition inhibits the proliferation and differentiation of adoptively transferred TCR transgenic CD4 T cells in response to infection. J Immunol 2006;176:3037-3043.

7. Hataye J, Moon JJ, Khoruts A, Reilly C, Jenkins MK. Naive and memory $\mathrm{CD}^{+} \mathrm{T}$ cell survival controlled by clonal abundance. Science 2006;312:114-116.

8. Rubtsov A, Strauch P, Digiacomo A, Hu J, Pelanda R, Torres RM. Lsc regulates marginal-zone $\mathrm{B}$ cell migration and adhesion and is required for the IgM T-dependent antibody response. Immunity 2005;23:527-538.

9. Swanson BJ, Baiu DC, Sandor M, Fabry Z, Hart MN. A small population of vasculitogenic $\mathrm{T}$ cells expands and has skewed $\mathrm{T}$ cell receptor usage after culture with syngeneic smooth muscle cells. J Autoimmun 2003;20:125-133.

10. Scheinfeld NS. Syndromic albinism: a review of genetics and phenotypes. Dermatol Online J 2003;9:5.

11. Targoff IN, Arnett FC, Berman L, O'Brien C, Reichlin M. Anti-KJ: a new antibody associated with the syndrome of polymyositis and interstitial lung disease. J Clin Invest 1989;84:162-172.

12. Pignone A, Scaletti C, Matucci-Cerinic M, Vazquez-Abad D, Meroni PL, Del Papa N, Falcini F, Generini S, Rothfield N, Cagnoni M. Antiendothelial cell antibodies in systemic sclerosis: significant association with vascular involvement and alveolo-capillary impairment. Clin Exp Rheumatol 1998;16:527-532.

13. Song Z, Marzilli L, Greenlee BM, Chen ES, Silver RF, Askin FB, Teirstein AS, Zhang Y, Cotter RJ, Moller DR. Mycobacterial catalaseperoxidase is a tissue antigen and target of the adaptive immune response in systemic sarcoidosis. $J$ Exp Med 2005;201:755-767.

14. Fontenot AP, Newman LS, Kotzin BL. Chronic beryllium disease: $\mathrm{T}$ cell recognition of a metal presented by HLA-DP. Clin Immunol 2001;100:4-14.

15. Lombardi G, Germain C, Uren J, Fiorillo MT, du Bois RM, JonesWilliams W, Saltini C, Sorrentino R, Lechler R. HLA-DP allelespecific $T$ cell responses to beryllium account for DP-associated susceptibility to chronic beryllium disease. J Immunol 2001;166:3549-3555.

16. Sawyer RT, Maier LA, Kittle LA, Newman LS. Chronic beryllium disease: a model interaction between innate and acquired immunity. Int Immunopharmacol 2002;2:249-261.

17. Diabetes Prevention Trial; Type 1 Diabetes Study Group. Effects of insulin in relatives of patients with type 1 diabetes mellitus. $N$ Engl $J$ Med 2002;346:1685-1691. 